\title{
Multi-Walled Carbon Nanotubes Enhance Methanogenesis from Diverse Organic Compounds in Anaerobic Sludge and River Sediments
}

\author{
Ana J. Cavaleiro ${ }^{1, *(\mathbb{C})}$, Andreia F. Salvador ${ }^{1}{ }^{(}$, Gilberto Martins $^{1}\left(\mathbb{D}\right.$, Cláudia C. Oliveira $\left.^{1}{ }^{(}\right)$, \\ Yuchen Liu ${ }^{2,+}$, Valdo R. Martins ${ }^{1}$, Ana Rita Castro ${ }^{1}{ }^{\mathbb{D}}$, Olívia Salomé G. P. Soares ${ }^{3}{ }^{\mathbb{D}}$, \\ Manuel Fernando R. Pereira ${ }^{3} \mathbb{D}$, Luciana Pereira ${ }^{1}{ }^{(D}$, Alette A. M. Langenhoff ${ }^{2}{ }^{\mathbb{D}}$, \\ Maria Alcina Pereira ${ }^{1}$ and M. Madalena Alves ${ }^{1}$ \\ 1 CEB - Centre of Biological Engineering, Campus de Gualtar, University of Minho, 4710-057 Braga, Portugal; \\ asalvador@ceb.uminho.pt (A.F.S.); gilberto.martins@deb.uminho.pt (G.M.); \\ claudia.ol.556@gmail.com (C.C.O.); valdomartins1991@gmail.com (V.R.M.); \\ ritacastro@deb.uminho.pt (A.R.C.); lucianapereira@deb.uminho.pt (L.P.); alcina@deb.uminho.pt (M.A.P.); \\ madalena.alves@deb.uminho.pt (M.M.A.) \\ 2 Sub-Department of Environmental Technology, Wageningen University \& Research, 6708 WG Wageningen, \\ The Netherlands; Y.Liu12@nuigalway.ie (Y.L.); alette.langenhoff@wur.nl (A.A.M.L.) \\ 3 Laboratory of Separation and Reaction Engineering-Laboratory of Catalysis and Materials (LSRE-LCM), \\ Faculty of Engineering, University of Porto, 4200-465 Porto, Portugal; salome.soares@fe.up.pt (O.S.G.P.S.); \\ fpereira@fe.up.pt (M.F.R.P.) \\ * Correspondence: acavaleiro@deb.uminho.pt; Tel.: +351253604423 \\ † Current affiliation: Microbial Ecology Laboratory, Microbiology, School of Natural Sciences and Ryan \\ Institute, National University of Ireland, H91 TK33 Galway, Ireland.
}

Received: 7 October 2020; Accepted: 13 November 2020; Published: 19 November 2020

\begin{abstract}
Conductive nanomaterials affect anaerobic digestion (AD) processes usually by improving methane production. Nevertheless, their effect on anaerobic communities, and particularly on specific trophic groups such as syntrophic bacteria or methanogens, is not extensively reported. In this work, we evaluate the effect of multi-walled carbon nanotubes (MWCNT) on the activity of two different anaerobic microbial communities: an anaerobic sludge and a river sediment. Methane production by anaerobic sludge was assessed in the presence of different MWCNT concentrations, with direct methanogenic substrates (acetate, hydrogen) and with typical syntrophic substrates (ethanol, butyrate). MWCNT accelerated the initial specific methane production rate (SMPR) from all compounds, with a more pronounced effect on the assays with acetate and butyrate, i.e., 2.1 and 2.6 times, respectively. In the incubations with hydrogen and ethanol, SMPR increased 1.1 and 1.2 times. Experiments with the river sediment were performed in the presence of MWCNT and MWCNT impregnated with $2 \%$ iron (MWCNT-Fe). Cumulative methane production was 10.2 and 4.5 times higher in the assays with MWCNT-Fe and MWCNT, respectively, than in the assays without MWCNT. This shows the high potential of MWCNT toward bioenergy production, in waste/wastewater treatment or ex situ bioremediation in anaerobic digesters.
\end{abstract}

Keywords: methane; syntrophic degradation; multi-walled carbon nanotubes; anaerobic sludge; sediment

\section{Introduction}

Anaerobic digestion (AD) is a multifunctional and flexible technology, offering solutions for the treatment and management of a multitude of organic wastes, while allowing the production of 
renewable energy carriers [1-4]. The generated methane, after upgrading to biomethane, can replace natural gas or be used for the production of electricity, combined heat and power, or chemicals $[1,5,6]$.

In $\mathrm{AD}$ systems, the conversion of organic matter to methane relies on the coordinated activity of several microbial groups $[7,8]$. After hydrolysis and acidogenesis, the majority of AD substrates is converted, inter alia, to volatile fatty acids, (VFA, e.g., butyrate) and alcohols (e.g., ethanol) $[7,8]$. The degradation of these compounds is generally syntrophic, yielding acetate and $\mathrm{H}_{2} /$ formate which are the direct substrates for methanogens. Syntrophic reactions are dependent on the activity of hydrogenotrophic methanogens or other $\mathrm{H}_{2}$ /formate-consumers, in order to turn these reactions thermodynamically feasible [9-11]. AD microbiomes are highly complex and maintaining a balance among the activities of different trophic groups is difficult when transient conditions are applied [12].

The influence of conductive materials on AD processes, and particularly on methane production, has gained attention during recent years [13-16]. These materials are reported to facilitate direct interspecies electron transfer (DIET) in anaerobic microbial communities, a mechanism that can prevail over indirect hydrogen and formate interspecies transfer [17-20]. Conductive materials are redox mediators, useful for catalysis due to their stability, reacting with many organic and inorganic compounds, and offering large surface areas [21,22]. For example, granular activated carbon (GAC) was reported to enrich for methanogens and accelerate the onset of methanogenesis during a reactor startup $[21,23,24]$. Other compounds, such as carbon cloth, graphite, and biochar were reported to affect the microbial community's composition, to enhance syntrophic ethanol metabolism, and methane production in upflow anaerobic sludge blanket (UASB) reactors [25]. Also, multi-walled carbon nanotubes (MWCNT) accelerated the methane production from butyrate in microbial enrichments [26]. MWCNT were also reported to accelerate methane production in pure cultures of hydrogenotrophic methanogens [27], showing a direct effect of MWCNT on the activity of methanogens independently of the occurrence of other mechanisms such as DIET. Additionally, conductive materials may also enhance microbial activity by providing a support for biofilm growth, rather than by their conductive characteristics $[28,29]$. On the other hand, carbon nanotubes (CNT) have also been reported as toxic, reducing the microbial growth. For example, Kang et al. [30] demonstrated that single-walled CNT can have a strong antimicrobial activity toward Escherichia coli, and MWCNT also decreased the microbial viability and activity in UASB reactors [31]. Reduced methanogenesis or complete inhibition by other conductive nanomaterials, such as ferrihydrite and carbon black, is also described [14,32].

Although there are several studies on the effect of conductive materials in anaerobic digestion, there are still no reports on their application in full scale bioreactors, nor studies on economic or environmental impact. In lab scale experiments, complex wastes such as real/synthetic wastewater, sludge, food wastes, swine manure or leachate have been tested, but most studies were performed with simple substrates, such as glucose, ethanol, or acetate [13-16]. While investigation on this topic still requires research and development, it is also important to deeply understand the effect of these materials on the activity of complex microbial communities which generate methane. In fact, the influence of conductive nanomaterials on anaerobic microbial communities is still not well understood, particularly their effect on specific groups of microorganisms such as syntrophic bacteria or methanogenic archaea. These are key players in the metabolic cascade of reactions that ultimately leads to the conversion of organic compounds into methane. In the present work, methane production from direct (acetate and hydrogen) and indirect (butyrate and ethanol) methanogenic substrates by anaerobic sludge was investigated in the presence of different MWCNT concentrations. Furthermore, the effect of MWCNT on methane production by the indigenous microorganisms in a river sediment was assessed, to evaluate the response of a different microbial community. Microbial communities in sediments are generally diverse and metabolically flexible, and methanogenesis is commonly the terminal step of organic matter mineralization in sediments $[33,34]$. Therefore, these constitute a completely different microbiome, making it an excellent candidate to verify whether the same or different effects are observed in the presence of MWCNT. MWCNT impregnated with $2 \%$ iron were also used in this experiment, as the 
impregnated nanomaterials present magnetic properties which may facilitate their recovery in applied biological treatment processes [35].

\section{Materials and Methods}

\subsection{Nanomaterials}

Commercial MWCNT (NC3100TM, Nanocyl SA., Sambreville, Belgium), with $1.5 \mu \mathrm{m}$ average length, $9.5 \mathrm{~nm}$ average diameter and more than $95 \%$ carbon purity (according to the supplier's technical data sheet) were used in the experiments. A magnetic carbon-based nanocomposite MWCNT with $2 \%$ iron (\% wt.) (MWCNT-Fe) was synthesized and characterized as described by Pereira et al. [35]. Briefly, the MWCNT sample is a mesoporous material and present a specific surface area of $283 \mathrm{~m}^{2} \mathrm{~g}^{-1}$, while the CNT-Fe has a surface area of $266 \mathrm{~m}^{2} \mathrm{~g}^{-1}$. The slight decrease of the surface area is due to the low amount of metal loaded. The MWCNT present neutral/basic properties and low amount of oxygen-containing surface groups.

\subsection{Effect of MWCNT on Methane Production by Anaerobic Sludge}

Anaerobic granular sludge was obtained from an anaerobic digester of a brewery's wastewater treatment plant, located in the municipality of Vila Franca de Xira (Lisbon district, Portugal). Sludge samples were collected by filling several $1.5 \mathrm{~L}$ bottles previously flushed with $\mathrm{N}_{2}$, and were immediately transported to the laboratory at $4{ }^{\circ} \mathrm{C}$. In the laboratory, the various samples were combined in a single container, flushed with $\mathrm{N}_{2}$ and preserved at $4{ }^{\circ} \mathrm{C}$. The granules were mechanically disrupted and added to each vial at a final volatile solids (VS) concentration of $3 \mathrm{~g} \mathrm{~L}^{-1}$. Assays were prepared as detailed by Holliger et al. [36], using the basal medium described by Alves et al. [37] with $\mathrm{Na}_{2} \mathrm{~S}$ $\left(1 \mathrm{mmol} \mathrm{L}^{-1}\right)$ instead of cysteine as reducing agent. Methane production was evaluated in $25 \mathrm{~mL}$ serum bottles containing $12.5 \mathrm{~mL}$ basal medium, in the presence of MWCNT $\left(0.5 \mathrm{~g} \mathrm{~L}^{-1}\right.$ or $\left.1.0 \mathrm{~g} \mathrm{~L}^{-1}\right)$ or in its absence, with acetate $\left(30 \mathrm{mmol} \mathrm{L}^{-1}\right)$, ethanol $\left(30 \mathrm{mmol} \mathrm{L}^{-1}\right)$ or butyrate $\left(15 \mathrm{mmol} \mathrm{L}^{-1}\right)$ as substrate (Figure 1). Substrates were added after overnight incubation $\left(37^{\circ} \mathrm{C}, 120 \mathrm{rpm}\right)$, and the excess pressure was vented. The assays with butyrate received two substrate additions, since very low activity was detected after the first butyrate addition (more than 10 days were necessary for complete butyrate degradation). For that, after day 10 of incubation, the headspace of the bottles was flushed with $\mathrm{N}_{2} / \mathrm{CO}_{2}(80: 20 \% \mathrm{v} / \mathrm{v})$ under sterile conditions, and $15 \mathrm{mmol} \mathrm{L}^{-1}$ of butyrate were added again. Blank assays, without any added substrate, were also performed. Another set of assays was prepared similarly, using $70 \mathrm{~mL}$ serum bottles and $12.5 \mathrm{~mL}$ basal medium (Figure 1), with $\mathrm{H}_{2} / \mathrm{CO}_{2}$ $\left(80: 20 \% v / v, 2.0 \times 10^{5} \mathrm{~Pa}\right)$ as carbon and energy source, and $\mathrm{N}_{2} / \mathrm{CO}_{2}\left(80: 20 \% v / v, 2.0 \times 10^{5} \mathrm{~Pa}\right)$ as blanks. All assays were performed in triplicate, and incubated at $37^{\circ} \mathrm{C}$, in the dark, with agitation $(120 \mathrm{rpm})$. Biogas production was monitored with a pressure transducer, which measured pressure variations in the closed bottles [37-39]. These measurements were performed every hour, during the first eight hours of incubation. For acetate and butyrate, since their degradation was slower, these measurements were continued, at larger time intervals, until the recorded values of methane production reached more than $50 \%$ of the theoretical (calculated based on the stoichiometry of the reactions presented in Table S1). Methane percentage in the biogas and VS concentration were determined at the end of the assays. Specific methane production rate (SMPR) was calculated from the highest slope of the linear initial region of the cumulative methane production curve, divided by the mass unit of sludge (in VS), and expressed as $\mathrm{mL} \mathrm{g}^{-1} \mathrm{~d}^{-1}$. The values obtained were corrected for standard temperature and pressure (STP) conditions [39]. 


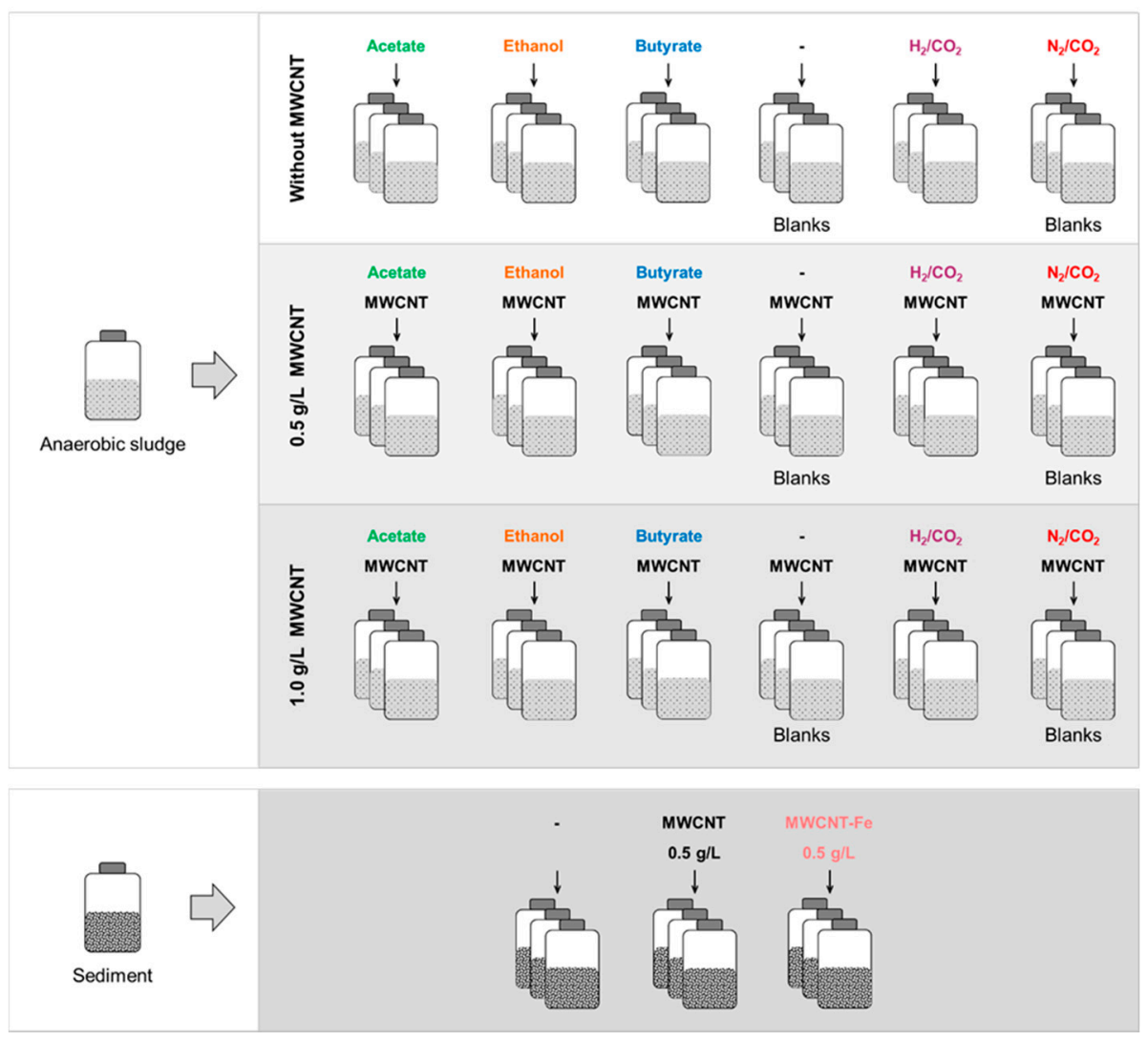

Figure 1. Scheme of the experimental procedure applied.

\subsection{Effect of MWCNT on Methane Production by the Indigenous Microorganisms in River Sediment}

Sediment samples were collected in Ribeira da Granja, close to the Granja beach (Vila Nova de Gaia, Portugal) (Figure S1). Samples were collected at 2-12 cm depth at three different locations, and immediately transported to the laboratory at $4{ }^{\circ} \mathrm{C}$. Then, samples were thoroughly homogenized and sieved through a $5 \mathrm{~mm}$ sieve. The homogenous sieved sediment was characterized in terms of organic matter content, total phosphate, iron(II) and total iron concentrations.

A bicarbonate-buffered mineral salt medium was prepared as described by Stams et al. [40]. Anaerobic conditions were promoted by boiling the medium prior to distribution in serum bottles, which were further sealed with butyl rubber stoppers and aluminum crimp caps. The bottles were flushed and pressurized with $\mathrm{N}_{2} / \mathrm{CO}_{2}\left(80: 20 \% v / v, 1.7 \times 10^{5} \mathrm{~Pa}\right)$. Before inoculation, the bottles were supplemented with vitamins and trace nutrients [40]. No reducing agent was added.

Assays were set up in $220 \mathrm{~mL}$ serum bottles, containing sediment $(25 \mathrm{~g})$, anaerobic basal medium $(75 \mathrm{~mL})$ and $0.5 \mathrm{~g} \mathrm{~L}^{-1}$ nanomaterial (MWCNT or MWCNT-Fe). Similar assays were set up without the nanomaterials (w/o MWCNT). No carbon source was supplemented. A scheme of the experimental procedure applied is shown in Figure 1. Assays were incubated at room temperature, in the dark, without agitation. $\mathrm{pH}$, oxidation-reduction potential (ORP) and methane concentration were measured at day 31,105, 169 and 199. Cumulative methane production values were corrected for STP conditions and expressed per mass unit of sediment.

\subsection{Analytical Methods}

Methane was measured using a gas chromatograph (Shimadzu, Kyoto, Japan) equipped with a flame ionization detector (FID) and a PoraPak Q column (80/100 mesh column, $2 \mathrm{~m} \times 1 / 8 \mathrm{in}, 2 \mathrm{~mm}$, stainless steel, Waters ${ }^{\mathrm{TM}}$, Milford, MA, USA) with nitrogen and argon as carrier gases at $30 \mathrm{~cm}^{3} \mathrm{~min}^{-1}$ and $5 \mathrm{~cm}^{3} \mathrm{~min}^{-1}$, respectively. The injector, column and detector temperatures were $110^{\circ} \mathrm{C}, 35^{\circ} \mathrm{C}$ and 
$220^{\circ} \mathrm{C}$, respectively. $\mathrm{pH}$ and ORP were measured with a $\mathrm{pH}$ probe (Jenway, Staffordshire, UK) and an ORP probe (VWR, Radnor, PA, USA), respectively. Organic matter content/VS content was determined as the weight difference due to ignition at $550{ }^{\circ} \mathrm{C}$ [41,42]. Total phosphate was quantified using cuvette tests (Hach Lange, Düsseldorf, Germany) and a Hach Lange DR2800 spectrophotometer, after digestion with $\mathrm{HCl}$ at $250{ }^{\circ} \mathrm{C}$ for $1 \mathrm{~h}$, as described by Romero-Gonzalez et al. [43]. Iron(II) quantification was performed as described in Lovley and Phillips [44]. Briefly, insoluble iron(II) present in the samples was solubilized during $1 \mathrm{~h}$ contact with $\mathrm{HCl}\left(0.5 \mathrm{~mol} \mathrm{~L}^{-1}\right)$. Total iron(II) was then quantified spectrophotometrically at $562 \mathrm{~nm}$ after reaction with ferrozine in $50 \mathrm{mmol} \mathrm{L}^{-1}$ HEPES buffer at $\mathrm{pH}$ 7.5. Iron(II) standards were prepared from ferrous ethylenediammonium sulfate. Total iron content was measured in samples extracted with $\mathrm{HCl}\left(0.5 \mathrm{~mol} \mathrm{~L}^{-1}\right)$ for $24 \mathrm{~h}$. The acid extract was then reacted with hydroxylamine- $\mathrm{HCl}\left(1.4 \mathrm{~mol} \mathrm{~L}^{-1}\right)$, which reduces iron(III) to iron (II), after which the ferrozine method was performed.

\subsection{Statistical Analysis}

The statistical significance of the differences detected in SMPR was evaluated for each substrate, using single factor analysis of variances (ANOVA). Statistical significance was established at $p<0.05$.

\section{Results and Discussion}

\subsection{Effect of MWCNT on Methane Production by Anaerobic Sludge}

The cumulative methane production curves obtained in the incubations with acetate and $\mathrm{H}_{2} / \mathrm{CO}_{2}$ are shown in Figure 2, and the calculated specific methane production rates (SMPR) are presented in Table 1 . The addition of MWCNT resulted in significantly faster $(p<0.004)$ methane production from acetate relatively to the assay without MWCNT, i.e., 1.6 and 2.1 times higher SMPR were verified in the presence of $0.5 \mathrm{~g} \mathrm{~L}^{-1}$ and $1.0 \mathrm{~g} \mathrm{~L}^{-1}$ MWCNT, respectively (Figure 2a, Tables 1 and 2). SMPR from acetate correlated highly with MWCNT concentration, as shown by the calculated correlation coefficient of 0.998 (Figure S2). No lag phases preceded the onset of methane production (Figure 2a). Regarding $\mathrm{H}_{2} / \mathrm{CO}_{2}$, SMPR increased circa $11 \%$ in the assays performed with $1.0 \mathrm{~g} \mathrm{~L}^{-1}$ MWCNT, when compared to the assays without MWCNT $(p<0.03)$, but no significant effect was observed with $0.5 \mathrm{~g} \mathrm{~L}^{-1}$ MWCNT (Figure 2b, Tables 1 and 2). Similarly, other studies reported stimulated acetoclastic but not hydrogenotrophic methanogenesis in assays with graphene (a planar representation of CNT) [45] or MWCNT-Fe [46]. The enrichment of Methanosaeta and the improvement of acetoclastic activity was also described in the presence of single-walled CNT [47] or biochar [48]. However, experiments with pure cultures of Methanobacterium and MWCNT $\left(5 \mathrm{~g} \mathrm{~L}^{-1}\right)$ showed an increase in the initial methane production rate of approximately 17 times [27], indicating that MWCNT positively affect the activity of hydrogenotrophic methanogens growing in pure cultures. In our experiments, the beneficial effects of MWCNT toward methanogens were more noticeable in the incubation with acetate than with $\mathrm{H}_{2} / \mathrm{CO}_{2}$. Nevertheless, faster methane production from both substrates was verified, especially at the higher MWCNT concentration tested, which shows the potential of MWCNT for increasing the efficiency of AD processes.

The activity of syntrophic bacteria was indirectly assessed in this work, by monitoring the methane produced from the degradation of ethanol (Figure 3a) and butyrate (Figure 3b). The SMPR from ethanol increased $11 \%$ and $22 \%$ in the assays performed with 0.5 and $1.0 \mathrm{~g} \mathrm{~L}^{-1} \mathrm{MWCNT}$, respectively, when compared to the assays without MWCNT (Tables 1 and 2), and a correlation coefficient of 1.000 was calculated for SMPR vs MWCNT concentration (Figure S2). Ethanol oxidation yields acetate and hydrogen/formate and is thermodynamically unfavorable at standard conditions (Equation (1) - Table S1), becoming thermodynamically feasible when these compounds are consumed by methanogens (Equations (3)-(5)-Table S1). MWCNT may have stimulated the activity of ethanol-degrading syntrophic bacteria, or/and the activity of methanogens, overall enhancing syntrophic ethanol conversion. 

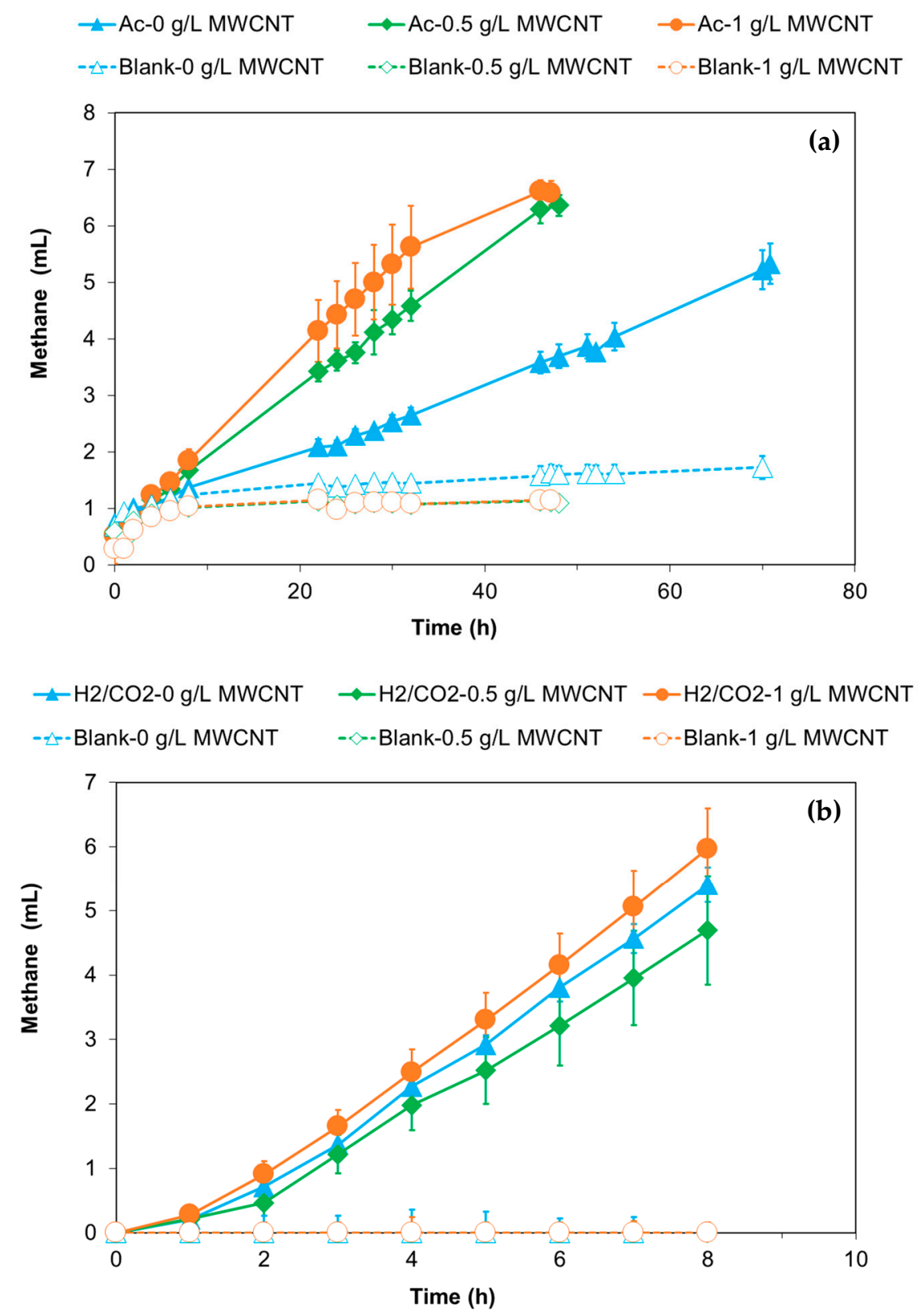

Figure 2. Cumulative methane production (at STP conditions) in the assays amended with acetate (a) or $\mathrm{H}_{2} / \mathrm{CO}_{2}(\mathbf{b})$, in the presence of different MWCNT concentrations: $0 \mathrm{~g} \mathrm{~L}^{-1}(\mathbf{\Lambda}), 0.5 \mathrm{~g} \mathrm{~L}^{-1}(\boldsymbol{\vee})$ and $1.0 \mathrm{~g}$ $\mathrm{L}^{-1}(\bullet)$. Blank assays (no added substrate) are also shown (open symbols). The results presented are the averages and standard deviations for triplicate assays.

Table 1. SMPR with different MWCNT concentrations. The SMPR of butyrate after $20 \mathrm{~h}$ of incubation is also shown.

\begin{tabular}{|c|c|c|c|c|c|c|}
\hline \multirow{2}{*}{$\begin{array}{l}\text { MWCNT } \\
\left(\mathrm{g} \mathrm{L}^{-1}\right)\end{array}$} & \multicolumn{6}{|c|}{ SMPR (mL $\left.\mathrm{g}^{-1} \mathrm{~d}^{-1}\right)$} \\
\hline & Acetate & $\mathrm{H}_{2} / \mathrm{CO}_{2}$ & Ethanol & $\begin{array}{l}\text { Butyrate } \\
\text { (1st add.) }\end{array}$ & $\begin{array}{l}\text { Butyrate } \\
\text { (2nd add.) }\end{array}$ & $\begin{array}{c}\text { Butyrate } \\
\text { (2nd add.) } t>20 \mathrm{~h}\end{array}$ \\
\hline 0 & $38 \pm 3^{a}$ & $394 \pm 10^{a}$ & $192 \pm 12^{a}$ & n.d. & $18 \pm 3^{a}$ & $40 \pm 0^{a}$ \\
\hline 0.5 & $62 \pm 4^{b}$ & $384 \pm 33^{\mathrm{a}, \mathrm{b}}$ & $214 \pm 4^{\mathrm{a}}$ & n.d. & $34 \pm 3^{a, b}$ & $47 \pm 0^{b}$ \\
\hline 1.0 & $82 \pm 10^{b}$ & $439 \pm 16^{b}$ & $235 \pm 9^{b}$ & n.d. & $47 \pm 3^{b}$ & $52 \pm 3^{c}$ \\
\hline
\end{tabular}

n.d.-not detected. ${ }^{\mathrm{a}, \mathrm{b}, \mathrm{c}}$ Different letters indicate statistically significant differences $(p<0.04)$. 
Table 2. Relative increase of the SMPR in the assays with MWCNT, compared to the assays without MWCNT. For butyrate, the increase of the SMPR in the period after $20 \mathrm{~h}$ of incubation is also shown.

\begin{tabular}{cccccc}
\hline $\begin{array}{c}\text { MWCNT }(\mathbf{g} \\
\left.\mathbf{L}^{-\mathbf{1}}\right)\end{array}$ & Acetate & $\mathbf{H}_{\mathbf{2}} / \mathrm{CO}_{\mathbf{2}}$ & Ethanol & $\begin{array}{c}\text { Butyrate } \\
\text { (2nd add.) }\end{array}$ & $\begin{array}{c}\text { Butyrate } \\
\text { (2nd add.) } \mathbf{~} \mathbf{~} \mathbf{2 0} \mathbf{~ h}\end{array}$ \\
\hline 0.5 & 1.6 & 1.0 & 1.1 & 1.9 & 1.2 \\
1 & 2.1 & 1.1 & 1.2 & 2.6 & 1.3 \\
\hline
\end{tabular}
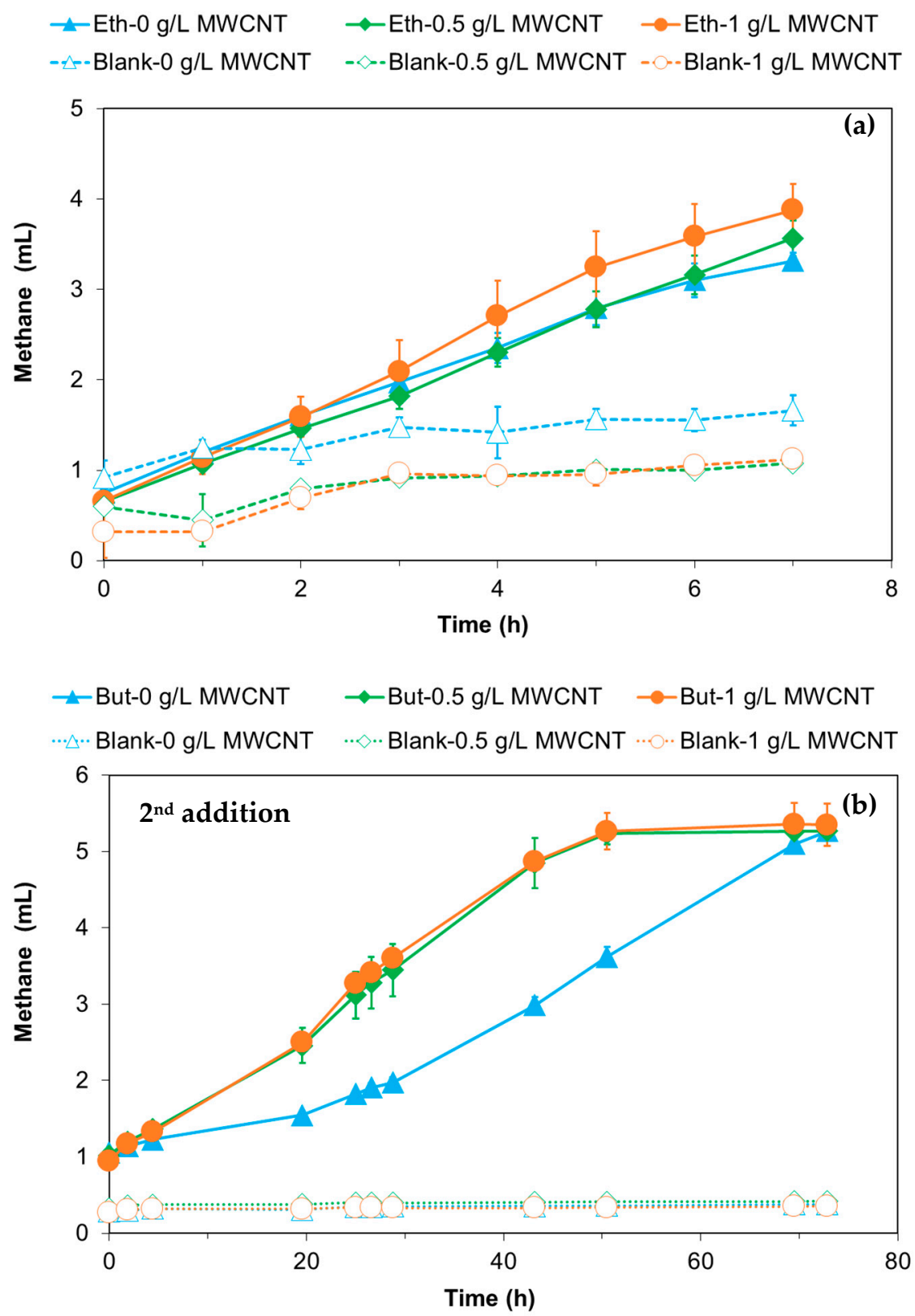

Figure 3. Cumulative methane production (at STP conditions) in the assays amended with ethanol (a) or butyrate (second addition) (b), in the presence of different MWCNT concentrations: $0 \mathrm{~g} \mathrm{~L}^{-1}$ $(\boldsymbol{\wedge}), 0.5 \mathrm{~g} \mathrm{~L}^{-1}(\bullet)$ and $1.0 \mathrm{~g} \mathrm{~L}^{-1}(\bullet)$. Blank assays (no added substrate) are also shown (open symbols). The results presented are the averages and standard deviations for triplicate assays.

The conversion of butyrate to methane took more than 10 days and no methane was produced during the first three days, showing the very low butyrate degrading activity of the community (Figure S3). Therefore, a second butyrate addition was performed, and the cumulative methane production obtained is shown in Figure $3 \mathrm{~b}$. In the presence of $0.5 \mathrm{~g} \mathrm{~L}^{-1}$ or $1.0 \mathrm{~g} \mathrm{~L}^{-1} \mathrm{MWCNT}$, the SMPR 
increased 1.9 and 2.6 fold, respectively (Tables 1 and 2), and was highly correlated with MWCNT concentrations $\left(R^{2}=0.997\right.$, Figure S2). The SMPR in the assays without MWCNT was as low as $18 \pm 3 \mathrm{~mL} \mathrm{~g}^{-1} \mathrm{~d}^{-1}$, reflecting the poor butyrate oxidation ability of the sludge (Table 1; Figure $3 \mathrm{~b}$ ). An increase of approximately 1.5 times in methane production was previously reported by Zhang and $\mathrm{Lu}$ [26] in butyrate-oxidizing enrichments containing MWCNT $\left(\sim 0.25 \mathrm{~g} \mathrm{~L}^{-1}\right)$, where Syntrophomonas and Methanoregula were dominant. Also, faster butyrate conversion to acetate and methane by Syntrophomonas wolfei in co-culture with Methanospirillum hungatei, in the presence of MWCNT, was described [27]. In our experiments, the positive effect of MWCNT on the initial methane production rate reflects an enhancement of the activity of syntrophic butyrate degrading bacteria, possibly due to the direct stimulation of hydrogenotrophic methanogens (Equations (2)-(4) and (6)-Table S1).

The slope of the cumulative methane production curves changed after $20 \mathrm{~h}$ of incubation (Figure 3b), and thus the SMPR for this period was also calculated (Table 1). These values increased with the increase of MWCNT concentrations $\left(R^{2}=1.000\right.$, Figure S2), and are statistically higher $(p<0.03)$ than in the experiments without MWCNT (Table 2). Considering that the sludge exhibited higher hydrogenotrophic than acetoclastic methanogenic activity, this second period $(t>20 h)$ was probably associated with the conversion of the acetate formed from butyrate oxidation, also pointing to a positive effect of MWCNT toward the activity of acetoclastic methanogens, ultimately improving complete butyrate conversion to methane (Equations (4) and (6)-Table S1).

The improvement of methane production by the presence of conductive materials was previously attributed to their capacity to mediate electron transfer between fatty acid or ethanol consuming bacteria and methanogenic archaea. In this study, both acetoclastic and hydrogenotrophic methanogenic activities were enhanced in the presence of MWCNT which might have contributed to the faster ethanol and butyrate conversion to methane. Overall, MWCNT accelerated methane production from all the tested compounds, and this increase was higher with acetate and butyrate, for which the activity of the sludge was lower.

\subsection{Effect of MWCNT on Methane Production by the Indigenous Microorganisms in River Sediment}

Since microbial communities may be differently affected by MWCNT, experiments were performed with a river sediment. Faster conversion of the natural organic matter to methane was achieved in the assays with MWCNT-Fe and MWCNT, relatively to the incubations without MWCNT (Figure 4). Additionally, 10.2 times and 4.5 times higher cumulative methane production was achieved in the presence of MWCNT-Fe and MWCNT, relatively to the absence of MWCNT (i.e., $130 \pm 19 \mathrm{~mL} \mathrm{~kg}^{-1}$, $57 \pm 26 \mathrm{~mL} \mathrm{~kg}^{-1}$ and $13 \pm 7 \mathrm{~mL} \mathrm{~kg}^{-1}$, respectively, after 169 days-Figure 4). Therefore, the stimulatory effects of MWCNT seem to be transversal to different microbial communities. These nanomaterials may have directly stimulated the methanogens, as referred in the previous section and also in [27], or accelerated interspecies electron transfers.

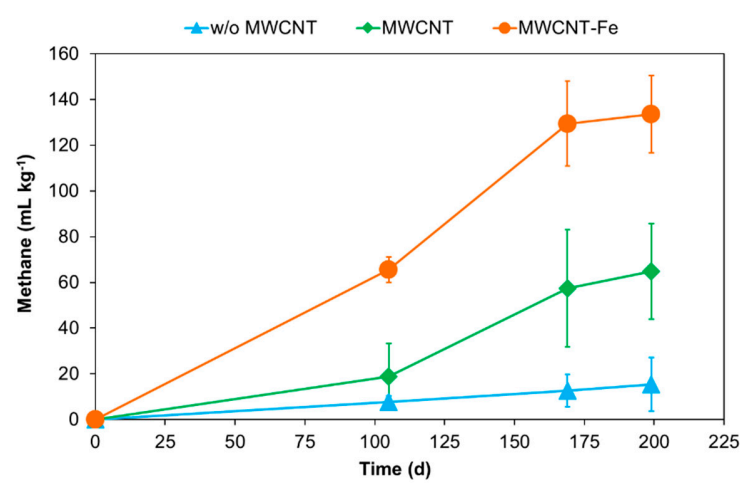

Figure 4. Cumulative methane production (at STP conditions) in the assays performed in the absence of MWCNT (w/o MWCNT, $\mathbf{\Delta}$ ), and in the presence of MWCNT $(\bullet)$ or MWCNT-Fe $(\bullet)$. The results presented are the averages and standard deviations for triplicate assays. 
Low organic matter content $(0.8 \pm 0.1 \%)$ was quantified in the sediment, which is typical of intertidal zones [33], and the slow methane production rate in the incubations without MWCNT (Figure 4) highlight the recalcitrant nature of the sedimentary organic matter. Phosphate, iron(II) and iron(III) concentrations were traceless. Since the culture medium did not contain sulfate neither nitrate, the presence of an alternative electron acceptor other than bicarbonate was ruled out. $\mathrm{pH}$ values were relatively constant over the time, varying between 6.7 and 7.1 in all the assays (data not shown). ORP varied between -100 and $-194 \mathrm{mV}$, and was higher ( $\sim 5$ to $50 \mathrm{mV}$ difference) in the assays with MWCNT-Fe, relatively to the other conditions tested (Figure S4). A similar effect was previously reported for MWCNT in assays with pure cultures of methanogens performed without reducing agent [27]. These authors described that the initial methane production rate increased with increasing MWCNT concentrations, and the ORP also increased, up to $-189 \mathrm{mV}$ [27].

Different mechanisms can support the stimulatory effects of MWCNT, as described previously by Pereira et al. [35]. In our assays, since MWCNT and MWCNT-Fe have similar textural characteristics (i.e., BET surface area of 283 and $266 \mathrm{~m}^{2} \mathrm{~g}^{-1}$, respectively), the higher stimulatory effect of MWCNT-Fe may be associated with the combined occurrence of different electron transfer mechanisms, including electron transfer from the $\mathrm{Fe}\left(\mathrm{Fe}^{2+}\right)$ impregnated in MWCNT to the carbon of the composites, and then to the final acceptor (i.e., $\mathrm{CO}_{2}$ reduction by methanogens), as represented in Figure 5. By receiving electrons from the oxidation of the organic matter, iron regeneration will probably occur during the process and act cyclically, accelerating the reaction rates. A similar mechanism was proposed by Pereira et al. [35] for the reduction of the azo dye Acid Orange 10. In that work, the involvement of iron in the mechanisms of electron transfer (represented as (3) and (4) in Figure 5) was demonstrated.

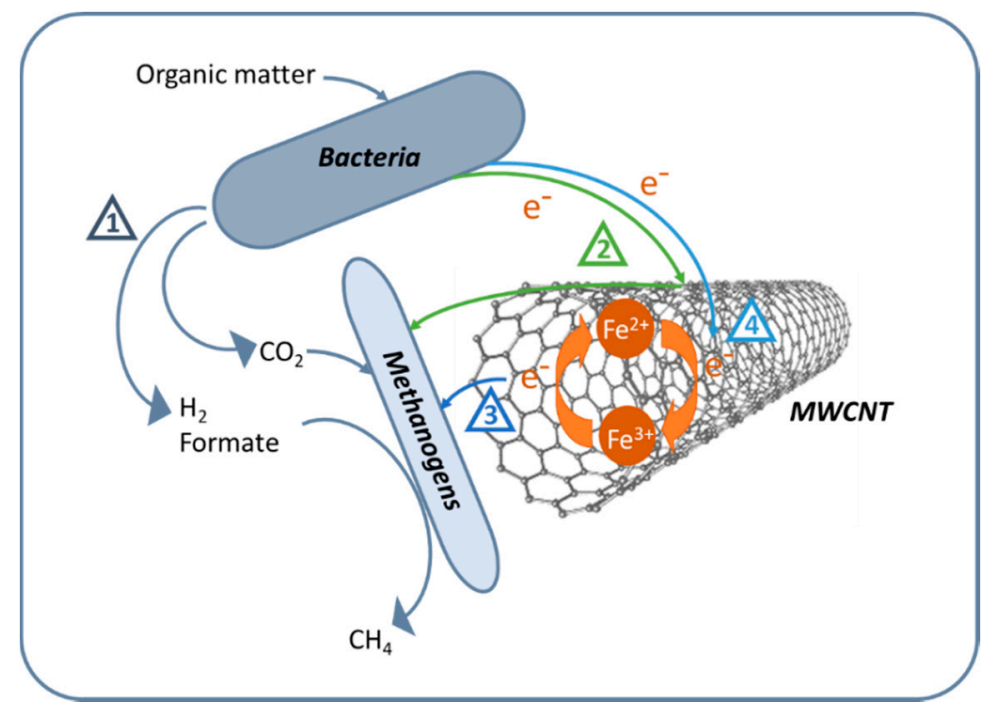

Figure 5. Proposed mechanism of organic matter oxidation in the presence of MWCNT-Fe (based on [35]). Three alternatives are depicted: electron flow from the organic matter oxidation by bacteria to the methanogens, via $\mathrm{H}_{2}$ /formate (1), or to the carbon of the composite, and then to the methanogens (2); electron flow from the $\mathrm{Fe}^{2+}$ impregnated in the MWCNT to the carbon of the composite, and then to the methanogens (3). Cyclical iron regeneration by electrons derived from the biological oxidation of organic matter is also represented (4).

\section{Conclusions and Future Perspectives}

The effects of different conductive carbon materials on AD have been thoroughly studied in recent years, but research gaps still exist, namely on the mechanism underlying these effects, and how these materials influence different key microbial groups. The results obtained in this work show that MWCNT accelerate methane production rates both from direct methanogenic substrates and from typical syntrophic substrates. Hence, the activity of acetoclastic and hydrogenotrophic methanogens 
was enhanced in the presence of MWCNT, which might have contributed to the faster syntrophic conversions of ethanol and butyrate. Additionally, faster and more extensive conversion of natural organic matter to methane was achieved by the sediment' native microbial community in the presence of MWCNT-Fe and MWCNT. Therefore, the stimulatory effects of MWCNT is transversal to different microbial communities, and appears to assume higher relevance when the microbial activity is lower (e.g., the incubations with acetate and butyrate). Overall, by enhancing the activity of complex methanogenic communities, the incorporation of MWCNT in AD processes will favor the application of higher organic loads, as described before by Lei et al. [49] during anaerobic digestion of leachate, and improve the efficiency of AD processes, speeding up slower bioprocesses. MWCNT addition to $\mathrm{AD}$ processes treating solid wastes, wastewaters or performing ex situ bioremediation of contaminated environmental matrixes thus represent a promising strategy for accelerating the recovery of their bioenergy value.

Further studies are required to assess the environmental and economic impacts of these bioprocess, including the costs of the anaerobic treatment process and the potential revenue of the generated biogas, as well as the costs of the nanomaterials. In addition, current knowledge needs to be expanded toward pilot scale and full scale experiments, and integrated with monitoring and control strategies, targeting the control, recovery, and reuse of MWCNT in the biological processes. During the operation of a UASB reactor for AO10 reduction, Pereira et al. [50] showed that MWCNT were efficiently retained inside the continuous reactor. Moreover, MWCNT could be recovered at the end of the operation, thus allowing their potential reuse. In another work [35], the same authors showed that due to the magnetic character of MWCNT-Fe, these nanomaterials were easily removed from the media and successfully applied in successive cycles of AO10 decolourization, without significant loss of their catalytic performance during the cycles. This magnetic character facilitates the recovery of the material, ultimately envisioning future applications in biological treatment processes.

Supplementary Materials: The following are available online at http://www.mdpi.com/2076-3417/10/22/8184/s1, Figure S1: Sediment sampling in Ribeira da Granja, Vila Nova de Gaia, Portugal, Figure S2: Linear correlation between MWCNT concentration and the specific methane production rate (SMPR) for acetate, $\mathrm{H}_{2} / \mathrm{CO}_{2}$, ethanol, and butyrate ( $2^{\text {nd }}$ addition, $\mathrm{t}=0-20 \mathrm{~h}$ and $\mathrm{t}>20 \mathrm{~h}$ ). Each point is the average of three experimental replicates, Figure S3: Pressure $(\mathrm{mV})$ increase in the assays amended with butyrate (first addition), in the presence of different MWCNT concentrations: $0 \mathrm{~g} \mathrm{~L}^{-1}(\mathbf{\Lambda}), 0.5 \mathrm{~g} \mathrm{~L}^{-1}(\bullet)$ and $1.0 \mathrm{~g} \mathrm{~L}^{-1}(\bullet)$. Blank assays (no added substrate) are also shown (open symbols). The results presented are the averages and standard deviations for triplicate assays, Figure S4: ORP values measured in the assays performed with river sediment in the absence of MWCNT (w/o MWCNT), and in the presence of MWCNT or MWCNT-Fe, Table S1: Reactions involved in ethanol and butyrate oxidation, and their corresponding standard Gibbs free energy changes.

Author Contributions: Conceptualization, A.J.C., G.M., M.A.P. and M.M.A.; methodology, A.J.C., A.F.S., G.M., M.A.P. and M.M.A.; validation, A.J.C., A.F.S., G.M. and A.R.C.; formal analysis, A.J.C., A.F.S., G.M., C.C.O. and V.R.M.; investigation, C.C.O., Y.L., V.R.M. and A.R.C.; resources, O.S.G.P.S., M.F.R.P., L.P. and M.M.A.; writing-original draft preparation, A.J.C., A.F.S. and G.M.; writing-review and editing, A.R.C., O.S.G.P.S., M.F.R.P., L.P., A.A.M.L., M.A.P. and M.M.A.; visualization, A.J.C., A.F.S. and G.M.; supervision, L.P., A.A.M.L., M.A.P. and M.M.A.; project administration, A.J.C., A.F.S. and G.M.; funding acquisition, A.J.C. and M.M.A. All authors have read and agreed to the published version of the manuscript.

Funding: This research was funded by the Portuguese Foundation for Science and Technology(FCT) under the scope of project MORE (POCI-01-0145-FEDER-016575), of the strategic funding of UIDB/04469/2020 unit and BioTecNorte operation (NORTE-01-0145-FEDER-000004) funded by the European Regional Development Fund under the scope of Norte2020-Programa Operacional Regional do Norte, as well as FCT/MCTES trough national funds (PIDDAC) and Base Funding-UIDB/50020/20 of the Associate Laboratory LSRE-LCM-funded by national funds rough FCT/MCTES (PIDDAC). Research of O.S.G.P.S. was funded by FCT under the Scientific Employment Stimulus-Institutional Call EECINST/00049/2018.

Conflicts of Interest: The authors declare no conflict of interest. The funders had no role in the design of the study; in the collection, analyses, or interpretation of data; in the writing of the manuscript, or in the decision to publish the results. 


\section{References}

1. Fagerström, A.; Al Seadi, T.; Rasi, S.; Briseid, T. The Role of Anaerobic Digestion and Biogas in the Circular Economy; Murphy, J.D., Ed.; IEA Bioenergy Task 37; IEA Bioenergy: Paris, France, 2018; pp. 1-24.

2. Muhammad Nasir, I.; Mohd Ghazi, T.I.; Omar, R. Production of biogas from solid organic wastes through anaerobic digestion: A review. Appl. Microbiol. Biotechnol. 2012, 95, 321-329. [CrossRef]

3. Castellano-Hinojosa, A.; Armato, C.; Pozo, C.; González-Martínez, A.; González-López, J. New concepts in anaerobic digestion processes: Recent advances and biological aspects. Appl. Microbiol. Biotechnol. 2018, 102, 5065-5076. [CrossRef] [PubMed]

4. Náthia-Neves, G.; Berni, M.; Dragone, G.; Mussatto, S.I.; Forster-Carneiro, T. Anaerobic digestion process: Technological aspects and recent developments. Int. J. Environ. Sci. Technol. 2018, 15, 2033-2046. [CrossRef]

5. Scarlat, N.; Dallemand, J.-F.; Fahl, F. Biogas: Developments and perspectives in Europe. Renew. Energy 2018, 129, 457-472. [CrossRef]

6. Child, M.; Kemfert, C.; Bogdanov, D.; Breyer, C. Flexible electricity generation, grid exchange and storage for the transition to a 100\% renewable energy system in Europe. Renew. Energy 2019, 139, 80-101. [CrossRef]

7. Van Lier, J.B.; Mahmoud, N.; Zeeman, G. Anaerobic wastewater treatment. In Biological Wastewater Treatment, Principles, Modelling and Design; Henze, M., van Loosdrecht, M.C.M., Ekama, G.A., Brdjanovic, D., Eds.; IWA Publishing: London, UK, 2008; Chapter 16; pp. 401-442.

8. Angelidaki, I.; Karakashev, D.; Batstone, D.J.; Plugge, C.M.; Stams, A.J. Biomethanation and its potential. Methods Enzymol. 2011, 494, 327-351. [CrossRef] [PubMed]

9. McInerney, M.J.; Struchtemeyer, C.G.; Sieber, J.; Mouttaki, H.; Stams, A.J.M.; Schink, B.; Rohlin, L.; Gunsalus, R.P. Physiology, ecology, phylogeny, and genomics of microorganisms capable of syntrophic metabolism. Ann. N. Y. Acad. Sci. 2008, 1125, 58-72. [CrossRef] [PubMed]

10. Stams, A.J.M.; Plugge, C.M. Electron transfer in syntrophic communities of anaerobic bacteria and archaea. Nat. Rev. Microbiol. 2009, 7, 568-577. [CrossRef]

11. Sieber, J.R.; McInerney, M.J.; Gunsalus, R.P. Genomic insights into syntrophy: The paradigm for anaerobic metabolic cooperation. Annu. Rev. Microbiol. 2012, 66, 429-452. [CrossRef]

12. Nguyen, D.; Wu, Z.; Shrestha, S.; Lee, P.H.; Raskin, L.; Khanal, S.K. Intermittent micro-aeration: New strategy to control volatile fatty acid accumulation in high organic loading anaerobic digestion. Water Res. 2019, 166, 115080. [CrossRef]

13. González, J.; Sánchez, M.E.; Gómez, X. Enhancing anaerobic digestion: The effect of carbon conductive materials. C-J. Carb. Res. 2018, 4, 59. [CrossRef]

14. Martins, G.; Salvador, A.F.; Pereira, L.; Alves, M.M. Methane production and conductive materials: A critical review. Environ. Sci. Technol. 2018, 52, 10241-10253. [CrossRef] [PubMed]

15. Zhang, J.; Zhao, W.; Zhang, H.; Wang, Z.; Fan, C.; Zang, L. Recent achievements in enhancing anaerobic digestion with carbon-based functional materials. Bioresour. Technol. 2018, 266, 555-567. [CrossRef] [PubMed]

16. Wu, Y.; Wang, S.; Liang, D.; Li, N. Conductive materials in anaerobic digestion: From mechanism to application. Bioresour. Technol. 2020, 298, 122403. [CrossRef]

17. Shrestha, P.M.; Rotaru, A.-E.; Aklujkar, M.; Liu, F.; Shrestha, M.; Summers, Z.M.; Malvankar, N.; Flores, D.C.; Lovley, D.R. Syntrophic growth with direct interspecies electron transfer as the primary mechanism for energy exchange. Environ. Microbiol. Rep. 2013, 5, 904-910. [CrossRef] [PubMed]

18. Wang, L.Y.; Nevin, K.P.; Woodard, T.L.; Mu, B.Z.; Lovley, D.R. Expanding the diet for DIET: Electron donors supporting direct interspecies electron transfer (DIET) in defined co-cultures. Front. Microbiol. 2016, 7, 236. [CrossRef] [PubMed]

19. Lovley, D.R. Happy together: Microbial communities that hook up to swap electrons. ISME J. 2017, 11, 327-336. [CrossRef]

20. Baek, G.; Kim, J.; Kim, J.; Lee, C. Role and potential of direct interspecies electron transfer in anaerobic digestion. Energies 2018, 11, 107. [CrossRef]

21. Liu, F.; Rotaru, A.E.; Shrestha, P.M.; Malvankar, N.S.; Nevin, K.P.; Lovley, D.R. Promoting direct interspecies electron transfer with activated carbon. Energy Environ. Sci. 2012, 5, 8982-8989. [CrossRef]

22. Figueiredo, J.L. Functionalization of porous carbons for catalytic applications. J. Mater. Chem. A 2013, 1, 9351-9364. [CrossRef] 
23. Xu, S.; He, C.; Luo, L.; Lü, F.; He, P.; Cui, L. Comparing activated carbon of different particle sizes on enhancing methane generation in upflow anaerobic digester. Bioresour. Technol. 2015, 196, 606-612. [CrossRef] [PubMed]

24. Lee, J.-Y.; Lee, S.-H.; Park, H.-D. Enrichment of specific electro-active microorganisms and enhancement of methane production by adding granular activated carbon in anaerobic reactors. Bioresour. Technol. 2016, 205, 205-212. [CrossRef] [PubMed]

25. Zhao, Z.; Zhang, Y.; Woodard, T.L.; Nevin, K.P.; Lovley, D.R. Enhancing syntrophic metabolism in up-flow anaerobic sludge blanket reactors with conductive carbon materials. Bioresour. Technol. 2015, 191, 140-145. [CrossRef] [PubMed]

26. Zhang, J.; Lu, Y. Conductive $\mathrm{Fe}_{3} \mathrm{O}_{4}$ nanoparticles accelerate syntrophic methane production from butyrate oxidation in two different lake sediments. Front. Microbiol. 2016, 7, 1316. [CrossRef] [PubMed]

27. Salvador, A.F.; Martins, G.; Melle-Franco, M.; Serpa, R.; Stams, A.J.M.; Cavaleiro, A.J.; Pereira, M.A.; Alves, M.M. Carbon nanotubes accelerate methane production in pure cultures of methanogens and in a syntrophic coculture. Environ. Microbiol. 2017, 19, 2727-2739. [CrossRef] [PubMed]

28. De Vrieze, J.; Gildemyn, S.; Arends, J.B.A.; Vanwonterghem, I.; Verbeken, K.; Boon, N.; Verstraete, W.; Tyson, G.W.; Hennebel, T.; Rabaey, K. Biomass retention on electrodes rather than electrical current enhances stability in anaerobic digestion. Water Res. 2014, 54, 211-221. [CrossRef] [PubMed]

29. Tremblay, P.-L.; Angenent, L.T.; Zhang, T. Extracellular electron uptake: Among autotrophs and mediated by surfaces. Trends Biotechnol. 2017, 35, 360-371. [CrossRef]

30. Kang, S.; Herzberg, M.; Rodrigues, D.F.; Elimelech, M. Antibacterial effects of carbon nanotubes: Size does matter! Langmuir 2008, 24, 6409-6413. [CrossRef]

31. Yadav, T.; Mungray, A.A.; Mungray, A.K. Effect of multiwalled carbon nanotubes on UASB microbial consortium. Environ. Sci. Pollut. Res. 2016, 23, 4063-4072. [CrossRef]

32. Fujinawa, K.; Nagoya, M.; Kouzuma, A.; Watanabe, K. Conductive carbon nanoparticles inhibit methanogens and stabilize hydrogen production in microbial electrolysis cells. Appl. Microbiol. Biotechnol. 2019, 103, 6385-6392. [CrossRef]

33. Volkman, J.K.; Rohjans, D.; Rullkötter, J.; Scholz-Böttcher, B.M.; Liebezeit, G. Sources and diagenesis of organic matter in tidal flat sediments from the German Wadden Sea. Cont. Shelf Res. 2000, 20, 1139-1158. [CrossRef]

34. Ferry, J.G.; Lessner, D.J. Methanogenesis in marine sediments. Ann. N. Y. Acad. Sci. 2008, 1125, 147-157. [CrossRef] [PubMed]

35. Pereira, L.; Dias, P.; Soares, O.S.G.P.; Ramalho, P.S.F.; Pereira, M.F.R.; Alves, M.M. Synthesis, characterization and application of magnetic carbon materials as electron shuttles for the biological and chemical reduction of the azo dye Acid Orange 10. Appl. Catal. B Environ. 2017, 212, 175-184. [CrossRef]

36. Holliger, C.; Alves, M.; Andrade, D.; Angelidaki, I.; Astals, S.; Baier, U.; Bougrier, C.; Buffière, P.; Carballa, M.; de Wilde, V.; et al. Towards a standardization of biomethane potential tests. Water Sci. Technol. 2016, 74, 2515-2522. [CrossRef] [PubMed]

37. Alves, M.M.; Mota Vieira, J.A.; Álvares Pereira, R.M.; Pereira, M.A.; Mota, M. Effect of lipids and oleic acid on biomass development in anaerobic fixed-bed reactors. Part I: Biofilm growth and activity. Water Res. 2001, 35, 255-263. [CrossRef]

38. Colleran, E.; Concannon, F.; Golden, T.; Geoghegan, F.; Coates, J. Use of methanogenic activity tests to characterize anaerobic sludges, screen for anaerobic biodegradability and determine toxicity threshold against individual anaerobic trophic groups and species. Water Sci. Technol. 1992, 25, 31-40. [CrossRef]

39. Coates, J.D.; Coughlan, M.F.; Colleran, E. Simple method for the measurement of the hydrogenotrophic methanogenic activity of anaerobic sludges. J. Microbiol. Methods 1996, 26, 237-246. [CrossRef]

40. Stams, A.J.M.; Van Dijk, J.B.; Dijkema, C.; Plugge, C.M. Growth of syntrophic propionate-oxidizing bacteria with fumarate in the absence of methanogenic bacteria. Appl. Environ. Microbiol. 1993, 59, 1114-1119. [CrossRef]

41. Martins, G.; Henriques, I.; Ribeiro, D.C.; Correia, A.; Bodelier, P.L.E.; Cruz, J.V.; Brito, A.G.; Nogueira, R. Bacterial diversity and geochemical profiles in sediments from eutrophic Azorean lakes. Geomicrobiol. J. 2012, 29, 704-715. [CrossRef]

42. APHA, AWWA, WPCF. Standard Methods for the Examination of Water and Wastewater, 20th ed.; APHA-AWWA-WEF: Washington, DC, USA, 1998. 
43. Romero-González, M.E.; Zambrano, E.; Mesa, J.; Ledo de Medina, H. Fractional phosphate composition in sediments from a tropical river (Catatumbo River, Venezuela). Hydrobiologia 2001, 450, 47-55. [CrossRef]

44. Lovley, D.R.; Phillips, E.J.P. Organic matter mineralization with the reduction of ferric iron in anaerobic sediments. Appl. Environ. Microbiol. 1986, 51, 683-689. [CrossRef] [PubMed]

45. Tian, T.; Qiao, S.; Li, X.; Zhang, M.; Zhou, J. Nano-graphene induced positive effects on methanogenesis in anaerobic digestion. Bioresour. Technol. 2017, 224, 41-47. [CrossRef] [PubMed]

46. Martins, V.R.; Martins, G.; Castro, A.R.; Pereira, L.; Alves, M.M.; Cavaleiro, A.J.; Soares, O.S.G.P.; Pereira, M.F.R. Microbial conversion of oily wastes to methane: Effect of ferric nanomaterials. In Wastes: Solutions, Treatments and Opportunities III; Vilarinho, C., Castro, F., Gonçalves, M., Fernando, A.L., Eds.; CRC Press, Taylor \& Francis Group: London, UK, 2019; pp. 339-345. [CrossRef]

47. Li, L.-L.; Tong, Z.-H.; Fang, C.-Y.; Chu, J.; Yu, H.-Q. Response of anaerobic granular sludge to single-wall carbon nanotube exposure. Water Res. 2015, 70, 1-8. [CrossRef] [PubMed]

48. Zhao, Z.; Zhang, Y.; Holmes, D.E.; Dang, Y.; Woodard, T.L.; Nevin, K.P.; Lovley, D.R. Potential enhancement of direct interspecies electron transfer for syntrophic metabolism of propionate and butyrate with biochar in up-flow anaerobic sludge blanket reactors. Bioresour. Technol. 2016, 209, 148-156. [CrossRef] [PubMed]

49. Lei, Y.; Sun, D.; Dang, Y.; Chen, H.; Zhao, Z.; Zhang, Y.; Holmes, D.E. Stimulation of methanogenesis in anaerobic digesters treating leachate from a municipal solid waste incineration plant with carbon cloth. Biores. Technol. 2016, 222, 270-276. [CrossRef]

50. Pereira, R.A.; Salvador, A.F.; Dias, P.; Pereira, M.F.R.; Alves, M.M.; Pereira, L. Perspectives on carbon materials as powerful catalysts in continuous anaerobic bioreactors. Water Res. 2016, 101, 441-447. [CrossRef]

Publisher's Note: MDPI stays neutral with regard to jurisdictional claims in published maps and institutional affiliations. 